\title{
Violence against women: caracteristics of head and neck injuries
}

\author{
Violência contra a mulher: características das lesões de cabeça e pescoço
}

\author{
Talita Lima de CASTRO' \\ Rachel Lima Ribeiro TINOCO² \\ Laíse Nascimento Correia LIMA $^{3}$ \\ Luiz Renato da Silveira COSTA ${ }^{4}$ \\ Luiz FRANCESQUINI JÚNIOR'1 \\ Eduardo DARUGE JÚNIOR
}

\section{ABSTRACT}

\section{Objective}

This study aimed to investigate the characteristics of aggression in head and neck regions suffered by women who are victims of gender violence, and to analyze the variation in the number of cases before and after the enactment of the Maria da Penha Law.

\section{Methods}

A survey was conducted on the records of examinations of personal injury made in the Department of Forensic Medicine in Vitória, in the Brazilian state of Espirito Santo. The study included women victims of bodily injury, referred as a result of domestic, family or conjugal violence, aged between 11 and 80 .

\section{Results}

The number of cases analyzed in this study exhibited an oscillation during the years studied. The results reveal that female victims are, in most cases, young, aged between 20 and 30, single and do not work outside the home. The victim's husband or partner was the main offender, mostly using parts of the body, like the hands and feet, as the means of aggression. The most frequent craniofacial injuries were ecchymosis and abrasions, more often in orbital, cervical and frontal regions.

\section{Conclusions}

The characteristics related to violence against women obtained through this study are of great importance and should be highlighted and publicized, to encourage implementation of public policies and practical actions of acceptance and recognition of such violence, including the insertion of the Forensic Dentist on the staff of experts in all Institutes of Forensic Medicine in the country.

Indexing terms: Domestic violence. Expert testimony. Facial injuries. Forensic dentistry. Violence against women.

\section{RESUMO}

\section{Objetivo}

O presente trabalho buscou levantar as características das agressões em regiões de cabeça e pescoço sofridas por mulheres vítimas de violência de gênero e analisar a variação do número de casos antes e depois da promulgação da Lei Maria da Penha.

\section{Métodos}

Foi realizado um levantamento nos registros dos exames de lesão corporal realizados no Departamento Médico Legal de Vitória, Espírito Santo. Foram incluídas mulheres vítimas de lesões corporais, encaminhadas em decorrência de violência doméstica, familiar ou conjugal com idade entre 11 e 80 anos.

\section{Resultados}

A quantidade de casos analisados nesse estudo exibiu uma oscilação durante os anos estudados. Os resultados revelam que a mulher vitimizada é, na maior parte dos casos, jovem, numa faixa etária entre 20 e 30 anos e solteira, e não trabalha fora de casa. O companheiro ou marido da vítima foi o principal agressor, utilizando principalmente segmentos do corpo, como mãos e pés, como meio de agressão. As lesões craniofaciais mais encontradas foram equimose e escoriação, mais frequentes nas regiões orbitária, cervical e frontal.

\section{Conclusão}

As características relacionadas à violência contra a mulher obtidas pelo trabalho têm grande importância e devem ser evidenciadas e divulgadas, a fim de que políticas públicas sejam implantadas e ações práticas de acolhimento e reconhecimento desse tipo de violência sejam tomadas, incluindo a inserção do Odontolegista no quadro de peritos de todos os Institutos Médicos Legais do país.

Termos de indexação: Violência doméstica. Prova pericial. Traumatismos faciais. Odontologia legal. Violência contra a mulher.

\footnotetext{
${ }^{1}$ Universidade Estadual de Campinas, Faculdade de Odontologia. Av. Limeira, 901, Areião, 13414-903, Piracicaba, SP, Brasil. Correspondência para / Correspondence to: TL CASTRO. E-mail: <talitalima01@hotmail.com>.

${ }^{2}$ Universidade Salgado de Oliveira, Faculdade de Odontologia. Niterói, RJ, Brasil.

${ }^{3}$ Universidade Federal do Maranhão, Departamento de Odontologia I. São Luís, MA, Brasil.

${ }^{4}$ Polícia Civil do Espírito Santo, Departamento Médico Legal de Vitória. Vitória, ES, Brasil.
} 


\section{INTRODUCTION}

Among the various forms of violence witnessed today, we find violence practiced against women based on gender inferiority, which can manifest itself through any commission or omission that may cause death, injury, physical, sexual or psychological suffering, or even moral or property damage. Domestic, family and conjugal violence are terms used to denominate the problem when this takes place in the family living environment, by related individuals or where there is an intimate relationship ${ }^{1-2}$, and its occurrence is recognized by the World Health Organization (WHO) as a public health issue ${ }^{3}$.

In August 2006, in Brazil, Law 11.340 was enacted', dubbed the Maria da Penha law, created with the aim of curbing domestic and family violence against women, representing for Brazil an advance in the legal treatment of injuries of a gender nature.

In this context, a variety of studies on this topic has demonstrated a similar pattern in cases involving gender violence. The victims mainly comprise youngsters on low incomes and belonging to the disadvantaged social class. The offender profile, for the most part, is male and the victim's current or former partner. In the majority of cases, the part of the body most affected is the head and the incident takes place in the domestic setting ${ }^{4-9}$.

Despite the importance of studying injuries in general, many studies on gender violence include injuries to any part of the body and do not take into consideration the need to study the specific characteristics of the orofacial region and the damage that may ensue in these areas. Essential functions such as breathing, chewing, swallowing and voicing, reside in the craniofacial region and aggression affecting this area could lead to significant functional alterations. Moreover, the face is the center of human attention and is very valuable in the context of social life, carrying with it great emotional and functional importance ${ }^{10}$.

Given the above, the goal of the present study was to conduct a survey of the characteristics of aggression in the region of the head and neck suffered by female victims of domestic, family or conjugal violence, in the metropolitan region of Vitória, in the Brazilian state of Espírito Santo, investigated by the Department of Forensic Medicine between 2004 and 2008, and to analyze the variation in the number of cases before and after the enactment of the Maria da Penha law of 2006, so as to contribute to the systematic study into violence against women, given its importance in matters of safety and public health.

\section{METHODS}

The present study presents a descriptive, retrospective and epidemiological survey of the records of corpus delicti examinations of women who have been the victims of domestic violence, between 2004 and 2008, in other words, two years before and two years after the Maria da Penha law came into force. The survey was carried out on the Archives of Vitoria's Department of Forensic Medicine, the agency responsible for carrying out corpus delicti examinations in the Greater Vitória Metropolitan Region, linked to the Civilian Police in the Brazilian state of Espírito Santo.

Three months from each year were selected for comparison over the five years included in the study, such that the month of March was drawn as the first of the four months of the year and the months of July and November were subsequently added to the sample, establishing an equivalent interval between the three.

In terms of the inclusion criteria, only those reports were evaluated that related to orofacial injuries in females aged between 11 and 80 and resulting from domestic, family or conjugal violence, as described in Law 11.340/2006, which, would typically fall under the aforementioned norm through the strict sense of the legal text. Information on the type of violence suffered was taken from the report history, according to the offender referred to by the victims, for inclusion or otherwise in the study. Accordingly, cases of non-family, interpersonal violence were excluded, such as cases of aggression by neighbors, school colleagues or coworkers, and other offenders not germane to the circle of domestic or family relationships Similarly, cases of traffic accidents, professional error sexual violence and those incidents that did not result in orofacial injury, were not analyzed.

The following data were extracted from the reports: victim's age, occupation or profession, marital status, city of origin, nature of relationship with the offender, number of offenders, the length of time between the assault and the examination, the day of the week on which the event occurred, the object used in the attack, and the type and location of the injury.

The identities of the study participants were kept confidential, as were any data that would allow them to be identified. This study complied with all the ethical standards drawn up in the Declaration of Helsinki and was approved by the Research Ethics Committee at the UNICAMP Faculty of Dentistry in Piracicaba, under reference number 046/2009. 


\section{RESULTS}

A total of 1,589 reports were found relating to women who were victims of gender violence, of which 927 (58\%) reported oral or craniofacial injuries and which, therefore, made up the selected sample.

The number of cases oscillated during the years of the study, though without evidence of a specific trend over time. The highest number of cases was observed in 2005, the year prior to the enactment of Law 11.340/2006, while the lowest number was in 2004, followed by 2007 , the year following the aforementioned law.

The number of reports issued prior to the Maria da Penha law, in 2004 and 2005, and in March 2006, was 374 , while the number of cases studied, relating to the period after the enactment of the norm, encompassing November 2006 and the years 2007 and 2008, was 487, showing an increase of $30.21 \%$ after the law was enacted.

\section{Victim profile}

As far as the victims' ages are concerned, most of the cases $(64.95 \%)$ are concentrated in the 25 to 35 age range $(33.23 \%)$, followed by 15 to $25(31.72 \%)$, as shown in Table 1.

The majority of women claimed to be single (54.69\%), with the group containing married women comprising $25.13 \%$ of victims. As for activities exercised, $25 \%$ of women did not work outside the home and $10.68 \%$ were domestic employees.

Table 1. Victim profile.

\begin{tabular}{|c|c|c|}
\hline Characteristic & Frequecy & Percentage \\
\hline Age & 927 & 100 \\
\hline $15--25$ & 294 & 31.72 \\
\hline $35-45$ & 174 & 18.77 \\
\hline $45--\mid 55$ & 82 & 8.85 \\
\hline $55-\mid 65$ & 20 & 2.16 \\
\hline $75--\mid 80$ & 1 & 0.11 \\
\hline Not registered & 6 & 0.65 \\
\hline Marital status of the victim & 927 & 100.00 \\
\hline Single & 507 & 54.69 \\
\hline Married & 233 & 25.13 \\
\hline Not registered & 36 & 3.88 \\
\hline Aggressor & 927 & 100.00 \\
\hline Domestic Partner & 347 & 37.43 \\
\hline Husband & 179 & 19.31 \\
\hline Ex-domestic partner & 127 & 13.70 \\
\hline Ex-boyfriend & 38 & 4.10 \\
\hline Brother/sister & 35 & 3.78 \\
\hline Boyfriend & 26 & 2.80 \\
\hline Ex-husband & 25 & 2.70 \\
\hline Brother-in-law/Ex-brother-in-law & 24 & 2.59 \\
\hline Others & 52 & 5.61 \\
\hline
\end{tabular}




\section{Offender profile}

The main offenders were partners (37.43\%) and husbands $(19.31 \%)$, totaling $56.74 \%$ of all cases. Other offenders include former partners and ex-husbands as well as other relatives. In $97.3 \%$ of cases, the victim said she had been attacked by just one offender.

Reference was made to the method of assault in just $22.65 \%$ of the reports. Of these, $64.93 \%$ recorded aggression by way of direct action by parts of the body, using the hands (punches, slaps, pushing) or feet (kicks).

\section{Data on assaults}

Around $78 \%$ of the reports and records noted the date of the assault and the day on which the examination was performed. It was, therefore, possible to analyze the time that elapsed between the aggression and the date of the examination, giving an average of 2.2 days, with a standard deviation of 10.27 . The majority of victims were either examined on the same day as the incident (23.62\%) or the day after (32.69\%).

By analyzing the frequency of assaults by day of the week, the research found a greater incidence of violence at weekends, showing that $20.82 \%$ of cases occurred on Sundays and $14.35 \%$ on Saturdays. In $20.71 \%$ (192) of records analyzed, this information was not recorded.

The reports analyzed evidenced a significant number of injuries, put at 1,293 by this study, as each female had one or more injuries. A high incidence of injuries perpetrated by blunt instruments was found, ecchymosis $(28.85 \%)$ and abrasions $(24.59 \%)$ being the most common (Table 2). The extraoral lesions presented were centered on the various regions of the head, face and neck, of which the most affected were the orbital $(17.14 \%)$, cervical $(16.63 \%)$ and frontal $(12.51 \%)$ regions.

Table 2. Characteristics of extraoral lesions.

\begin{tabular}{|c|c|c|}
\hline Characteristic & Frequecy & Percentage \\
\hline Injurya & 1293 & 100.00 \\
\hline Abrasions & 318 & 24.59 \\
\hline Hematoma & 129 & 9.98 \\
\hline Laceration & 124 & 9.59 \\
\hline Stab wound & 29 & 2.24 \\
\hline Blood boss & 9 & 0.70 \\
\hline Rubefaction & 7 & 0.54 \\
\hline Burn & 6 & 0.46 \\
\hline Bone Fracture & 3 & 0.23 \\
\hline Puncture wound & 2 & 0.15 \\
\hline Others & 11 & 0.85 \\
\hline Frontal & 173 & 12.51 \\
\hline Malar & 118 & 8.53 \\
\hline Labial & 117 & 8.46 \\
\hline Nasal & 108 & 7.81 \\
\hline Parietal & 86 & 6.22 \\
\hline Zygomatic & 83 & 6.00 \\
\hline Auricular & 46 & 3.33 \\
\hline Masseteric & 43 & 3.11 \\
\hline Hemiface & 37 & 2.68 \\
\hline Temporal & 35 & 2.53 \\
\hline Occipital & 35 & 2.53 \\
\hline
\end{tabular}
affected region. 
A record of intraoral lesions were found in 129 reports, amongst which ecchymosis and abrasions were the most common injuries (Table 3), and the labial mucosa was the area of the mouth most affected. Fifteen cases $(11.63 \%)$ related to lesions in one or more teeth, totaling 24 teeth with traumas. Of these, the most common was a tooth fracture, which occurred in $50 \%$ of tooth injuries and the element most frequently affected was the upper central incisor (41.67\%).

Table 3. Characteristics of intraoral lesions.

\begin{tabular}{|c|c|c|}
\hline Characteristic & Frequecy & Percentage \\
\hline Injury & 129 & 100.00 \\
\hline Ecchymosis & 43 & 33.33 \\
\hline Abrasions & 22 & 17.05 \\
\hline Laceration & 20 & 15.50 \\
\hline Dental injury & $15^{b}$ & 11.63 \\
\hline Incised wound & 10 & 7.75 \\
\hline Edema & 8 & 6.20 \\
\hline Hematoma & 6 & 4.65 \\
\hline Rubefaction & 2 & 1.55 \\
\hline Stab wound & 2 & 1.55 \\
\hline Bone Fracture & 1 & 0.78 \\
\hline Intraoral affected regions & 128 & 100.00 \\
\hline Labial Mucosa & 73 & 57.03 \\
\hline Teeth & 24 & 18.75 \\
\hline Oral Mucosa & 23 & 17.97 \\
\hline Gum & 7 & 5.47 \\
\hline Upper jaw & 1 & 0.78 \\
\hline affected teeth & $24^{b}$ & 100.00 \\
\hline Maxillary central incisor & 10 & 41.67 \\
\hline Maxillary lateral incisor & 6 & 25.00 \\
\hline Mandibular central incisor & 3 & 12.50 \\
\hline Maxillary Canine & 3 & 12.50 \\
\hline Maxillary 1st Premolar & 2 & 8.33 \\
\hline Dental injuries & 24 & 100.00 \\
\hline Dental Fracture & 12 & 50.00 \\
\hline Avulsion & 8 & 33.33 \\
\hline Luxation & 3 & 12.50 \\
\hline Subluxation & 1 & 4.17 \\
\hline
\end{tabular}

Note: ${ }^{b} \mathrm{As}$ in some cases the aggression affected more than one tooth, the number of people with alveolus-dental involvement (15) was different from the number of injured teeth (24).

\section{DISCUSSION}

The enactment of Law 11.340/2006 amended the Brazilian Criminal Code, increasing the maximum period of imprisonment and removing the possibility of alternative punishment for the offender, as well as establishing measures that could keep offenders far away from the victims and their children'. However, although generally applauded, this norm may fall short. The commission for the Convention on the Elimination of All Forms of Discrimination Against Women (CEDAW) stated that violence against women is still not recognized by society as a violation of human rights, such that effective measures are needed for monitoring the new law, through the collection of data, broken down by type of violence and by the relationship of perpetrator and victim ${ }^{11}$.

The number of cases analyzed in this study varied during the years studied, though without any evidence of a specific trend over time. Given this situation, there has been some discussion as to whether a period of two years after the enactment of the law is sufficient to change the paradigms in Brazilian society, given the entrenched inferiority of women in the family setup. Despite the victories achieved by women in the labor market and the efforts to apply what is written in the Brazilian Constitution, namely "men and women have equal rights and obligations (...)", many women are still mistreated inside the home, suffering in silence because of fear or shame, because of financial dependence or an affective bond with the assailant 5,12 .

Murder of women is the main cause of early death among women when analyzing the external causes of death $^{13}$. Between 2001 and 2011, mortality rates were observed, as a result of aggression, of 5.28 and 5.22 for every 100,000 women, in the respective periods before (2001-2006) and after (2007-2011) the aforementioned law came into force. By comparing these data, it can be seen that there was no statistically significant reduction in annual mortality rates on account of assaults on women, demonstrating that the norm that was established has probably not had any impact on this fact in Brazil ${ }^{14}$.

A study carried out in the Brazilian state of Ceará compared cases of gender violence that occurred in the period between 2001 and 2012 and sought to find evidence of differences between the period before the proclamation of the Maria da Penha law, and afterwards. The study revealed that the profile of women victims in Ceará remained flat over the years, but found an increase in the number of accusations and incident reports after the law, including the different types of gender violence, reducing the percentage of women who remained silent faced with the situation of the aggression suffered ${ }^{15}$.

In the future, continuous projects to monitor these data must be carried out, however with the following caveat: the increase in the number of cases may not signify 
an increase in aggression, but rather accusations by victims as a consequence of women's increasing awareness of their rights and protective measures. Moreover, it must be considered that many cases previously characterized as grievous bodily harm were, in fact, the results of domestic violence and, with Law 11.340/2006, they came to be recorded as such, which may have contributed to the percentage increase of $124.9 \%$ of cases of domestic or family violence between 2006 and 2007 in Rio de Janeiro ${ }^{16}$.

In this context it is prudent to stress that the understanding of the requesting authority in respect of the classification of occurrences may constitute a sampling bias if the typification made in the Incident Report, Police Inquiry or Legal Process of each case is taken into consideration, since episodes of domestic, family or conjugal violence which ought to fall under Law 11.340/2006 may be inappropriately characterized as grievous bodily harm, without due increase in the punishment introduced by the legal provision. Therefore, the cases analyzed in the present study were included according to information about the type of violence perpetrated on the report history, according to the offender referred to by the victims, selecting the cases of domestic, family and conjugal violence, as described in Law 11.340/2006, which would typically be classified in the aforementioned norm if the strict sense of the legal text is taken into consideration.

As far as victim profiles are concerned, in the sample evaluated here, women in a situation of gender violence are young, predominantly in the 25 to 35 age range, (33.44\%), followed by the 15 to 25 age range $(31.92 \%)$, with an average age of 31 . These data are in agreement with other studies $5-6,8,14-15,17-20$, in which the authors also encounter younger age groups and similar average ages.

According to the World Health Organization ${ }^{21}$, young women, particularly those between 15 and 19 years of age, are at higher risk of suffering violence by their partners. This may mean, in part, that younger men tend to be more violent than older men and that violence tends to occur from the outset of many relationships. Moreover, in some circumstances, younger women enjoy a less favorable socioeconomic situation than older women and may, therefore, be more vulnerable.

As for marital status, the present study noted a large number of single women being attacked (54.69\%), followed by married women $(25.13 \%)$, in agreement with some of the literature ${ }^{6-7,15,17}$. Some variations in respect of results found in other works $s^{8,18,20,22-23}$ may be down to the fact that many women who claim to be single, married or divorced, are actually just partners, cohabiting in a so-called common law marriage, without any legal form. As this item of information is recorded based on the spontaneous report by the woman, the proportion of women in a common-law marriage could be higher than that shown in the results.

The image of the offender, in the majority of cases examined (56.74\%), refers to the victim's partner, as previously noted $5,7,17-18,20$. It should, however, be stressed that if they were related to the variables "victim's age" and "bond with the offender", in women aged over 60, there could be a significant, proportional increase in the category "other family member" as the perpetrator of the violence, most commonly represented by the sons of the victims ${ }^{18}$.

Despite article 5 of Law 11.340/2006 proposing that personal relations protected by the provision are independent of sexual orientation, no reports of aggression were observed in homo-affective relationships in the present study. Thus, it may be inferred that an under-notification of this type of violence by homosexual women may have occurred, who may be suffering violence at the hands of their partners, but fail to mention the domestic or conjugal relationship during the recording of the occurrence. Thus, the resulting injuries are not typically classified under the Maria da Penha law, making it difficult to conduct a statistical survey of these events. This subject deserves greater visibility and further analysis, in order to guarantee legislative protection to the members of all family nuclei who find themselves in vulnerable situations ${ }^{24}$

In terms of the victim's occupation, the highest assault rates were observed amongst housewives (24.49\%), students $(9.6 \%)$ and domestic employees (10.68\%), which brings us in line with other studies, 15,22,25-26 and also infers that there is an inversely proportional relationship between a woman's income and the occurrence of violence ${ }^{18}$. For those women financially dependent on their partners, punishing the offender also results in the victim being punished, and they end up not making an accusation in the fear that they would be left unsupported, so they elect to put up with the abuse and cover up for their attackers ${ }^{17}$.

It can be seen that there was no lag between the act of aggression and the corpus delicti examination, as $72.82 \%$ of victims went to the Department of Forensic Medicine for examination within three days of the injurious event. However, it should be emphasized that, despite the notifications having been made soon after the assault, the decision to file an accusation does not always take 
place immediately after the initial act of aggression ${ }^{7}$. As for the day of the week on which the attack takes place, most events occur on weekends, in agreement with other studies ${ }^{7,14,17}$ which argues that the domestic environment is the most common scenario for family aggression, as it is safe from outside interference and as it is an environment ripe for further arguments and the aggravation of old grievances. The period of time that the offender and victim spend together is greater on Saturdays and Sundays, and commonplace, everyday topics can become a motive for fighting faced with an increasingly turbulent coexistence. Moreover, it should be stressed that the consumption of alcohol occurs most commonly at weekends, and it is a factor related to the occurrence of violent acts ${ }^{26}$. The use of this substance by men in aggressive situations is linked to around $40 \%$ of cases of violence against women ${ }^{23}$.

Of those cases where a record of the method employed to commit the assault was made, almost $65 \%$ were naked aggression, in other words, using parts of the body, the hands and feet, in the form of blows, slaps, kicks, etc. ${ }^{6}$. This information is in agreement with other studies ${ }^{7,17}$ and could be interpreted as proof that the agent did not commit a premeditated attack, nor had the intention to cause great harm to the victim.

What is also seen in the present work is the high number of oral and craniofacial injuries in the women examined. Around $58 \%$ of reports relating to victims of domestic, family or conjugal violence noted at least one head or neck lesion, enabling its inclusion in the study.

The same region was also the location most commonly injured in other studies conducted on female victims of bodily harm ${ }^{15,17,27}$, and also in women victims of homicide, in which the craniofacial complex was also the focus of around $58 \%$ of injuries found ${ }^{13}$.

It may be deduced that the prominence of the face, the possibility of hitting it with the hands or some or other instrument, and its vulnerability, end up making it an easy target in fights and physical skirmishes. The representativeness of an individual through the face and its figurative significance in social life should also be taken into consideration, as the face paints a portrait of the individual and reproduces their expressions and feelings, meaning that injuries in this area are a distinctive trademark that is difficult to conceal with clothing. This item of information might imply the offender's intention to leave his mark on the victim socially, as it is a highly conspicuous area, in order to humiliate the woman ${ }^{5}$. This region requires special attention during the work of investigation as its structures are of great value to us in terms of the vital functions of breathing, chewing, swallowing and voicing.

Head and neck lesions are a socioeconomic and institutional challenge that is still unresolved. Facial traumatology should be alert to the magnitude of this problem and should be prepared to cope with it based on practical, multidisciplinary studies, as the solution is different for each external cause studied, a topic in which interpersonal aggression demands important attention ${ }^{10}$.

Of the intraoral lesions, bruising and abrasions are the most frequent, coinciding with extraoral lesions. The regions most affected were the teeth and the labial and oral mucosa. Tooth fractures were observed in $50 \%$ of the teeth involved, while avulsion was notified at $33.3 \%$. It should be noted that only the front teeth and first upper premolars, the teeth which are visible in the smile region, were recorded as affected, and there were no cases of damage to the temporomandibular joint, although 310 injuries involved regions of the maxilla-mandibular complex.

It should be remembered that the Department of Forensic Medicine in Vitória has no forensic dentists on its staff and all examinations of bodily injuries are carried out by physicians. This hole could lead to an under-notification of the lesions present in the maxillo-mandibular complex, to the making of mistakes in the description of injuries and even to errors in the recording of the anatomic nomenclature attributed to the teeth ${ }^{27}$.

The dearth of professionals fit to exercise intraoral examinations in the Institute of Forensic Medicine carries with it a serious limitation for the investigations performed. When a physician carries out examinations which should technically be carried out by a forensic dentist, the rights of the victim are being usurped by the negative consequences arising from the omissions resulting from a physician performing a task which is legally the responsibility of a dental surgeon, the person legally responsible for "proceeding with the forensic dentistry investigation in civil, criminal, labor courts and in administrative courts"28.

When attempting to systematize the main obstacles to the implementation of care for women in situations of violence, one can see a marked disconnect or even lack of communication between the institutions responsible for caring for these victims, a precarious physical structure and the absence of qualified professionals ${ }^{24}$.

It is necessary to include the forensic dentist on the expert staff of all Institutes of Forensic Medicine in the country and provide these experts with refresher courses 
on Domestic Violence. Professionals who are involved in caring for these victims bring an essential infusion of practical knowledge from their day-to-day experience and their technical understanding. The care specialization should be built on concepts and methodologies mobilized by way of humanized, interdisciplinary and standardized procedures and interventions ${ }^{29}$.

As for women's attitudes to these acts of aggression, a study ${ }^{22}$ conducted in an organizational unit which offers help to women who have been assaulted, showed that around $30 \%$ of women sought medical assistance. Of these, $60 \%$ told the physician that their partner had been responsible, and $56 \%$ of these stated that the physician tried to convince them to denounce their partner or referred them to another professional, such as a psychologist or social welfare assistant. Of the health professionals involved, the orthopedist and dentist are the most frequently sought after by the victims ${ }^{17}$, given the high frequency of involvement of the regions of the face, head, arms and hands.

These professionals should pay particular attention to Law $10.778 / 2003^{30}$, which establishes the mandatory notification of cases of violence against women treated in both public and private health services. This notification is for epidemiological purposes and cannot be used in police or legal investigations, representing a fundamental measure for dimensioning the phenomenon of violence against women.

\section{CONCLUSION}

It may be concluded that women who are victims of violence are, in the majority of cases, young and without employment outside the home. The victim's husband or

\section{REFERENCES}

1. Brasil. Lei n. 11.340, de 7 de agosto de 2006. Cria mecanismos para coibir a violência doméstica e familiar contra a mulher e dá outras providências. Diário Oficial da União 2006. 8 ago [citado 2016 Mar 20]. Disponível em: <http://www.planalto.gov.br/ ccivil_03/_ato2004-2006/2006/lei/111340.htm>.

2. Casique LC, Furegato ARF. Violência contra mulheres: reflexões teóricas. Rev Latino-am Enferm. 2006;14(6):950-6. doi: 10.1590/S0104-11692006000600018

3. Organização Mundial de Saúde. Estudio multipaís de la OMS sobre salud de la mujer y violencia doméstica contra la mujer. Departamento Género y Salud de la Mujer. Grupo Orgánico Salud de la Familia y la Comunidad. Ginebra: Organización Mundial de la Salud; 2002 partner was the principal offender, using parts of his body as the weapon of assault. The most affected craniofacial areas were the orbital, cervical and frontal regions. The presence in the records of dental alveolar lesions revealed a prevalence of the involvement of the upper incisors, however the absence of forensic dentists in the Department of Forensic Medicine in Vitória could represent an undernotification of injuries in the stomatognathic system.

An understanding of the characteristics related to violence against women is of fundamental importance and must be evidenced and publicized so that public policy designed to confine the problem is implemented and practical actions of accepting and acknowledging this type of violence can be taken, including the inclusion of the forensic dentist in the staff of experts in all of the Institutes of Forensic Medicine around the country.

\section{Acknowledgements}

We thank the Department of Forensic Medicine in Vitória, Espírito Santo, for enabling this research, especially to the coroners Kátia Souza Carvalho and Romildo Rabbi, for collaboration and scientific incentive.

\section{Collaborators}

TL CASTRO: conception and design, acquisition, analysis and interpretation of data. RLR TINOCO: analysis and interpretation of data, drafting the article. LNC LIMA: drafting the article. LRS COSTA: acquisition of data. L FRANCESQUINI JÚNIOR: critical review for important intellectual content of the article. E DARUGE JÚNIOR: final approval of the version to be published.

4. Minayo MC de S. A difícil e lenta entrada da violência na agenda do setor saúde. Cad. Saúde Pública. 2004;20(3):646-7. doi: 10.1590/S0102-311X2004000300001

5. Rabello PM, Caldas-Júnior AF. Lesões faciais de mulheres agredidas fisicamente - Paraíba - Brasil. Odontol Clín-Científ. 2006;5(4):321-5.

6. Rezende EJC, Araújo TM, Moraes MAS, Santana JS da S, Radicchi R. Lesões buco-dentais em mulheres em situação de violência: um estudo piloto de casos periciados no IML de Belo Horizonte, MG. Rev Bras Epidemiol. 2007;10(2):202-14. doi: 10.1590/ S1415-790X2007000200008

7. Leôncio $K L$, Baldo $P L$, João VM, Biffi RG. O perfil de mulheres vitimizadas e de seus agressores. Rev Enferm. 2008;16(3):30712. 
8. Garcia MV, Ribeiro LA, Jorge MT, Pereira GR, Resende AP. Caracterização dos casos de violência contra a mulher atendidos em três serviços na cidade de Uberlândia, Minas Gerais, Brasil. Cad Saúde Pública. 2008;24(11):2551-2563. doi: 10.1590/ S0102-311X2008001100010.

9. Lamoglia CVA, Minayo MCS. Violência conjugal, um problema social e de saúde pública: estudo em uma delegacia do interior do Estado do Rio de Janeiro. Ciênc Saúde Coletiva. 2009;14(2):595604. doi: 10.1590/S1413-81232009000200028

10. Silva OMP, Panhoca L, Blachman IT. Traumatismos Faciais Causados pela Violência Ocorrida na Cidade de São Paulo, ao Longo do Século XX. Rev Odontol UNESP. 2003;32(2):81-5.

11. Brasil. Presidência da República. Secretaria Especial de Políticas para as Mulheres. VI Relatório Nacional Brasileiro. Convenção pela Eliminação de todas as Formas de Discriminação contra as Mulheres - CEDAW/Organizações das Nações Unidas. Brasília: Secretaria Especial de Políticas para as Mulheres; 2008.

12. Chesnais JC. Violência no Brasil. Causas e recomendações políticas para sua prevenção. Ciênc Saúde Coletiva. 1999;4(1):5369. doi: 10.1590/\$1413-81231999000100005

13. Oliveira MCA, Vieira ELR, Penha MRC, Melo EH, CaldasJúnior AF. Characterization of women victims of violent death in a metropolitan area of Northeast Brazil. RGO, Rev Gaúch Odontol. 2015;63(4):439-45. doi: 10.1590/1981863720150003000102883

14. Garcia LP, Freitas LRS, Höfelmann DA. Avaliação do impacto da Lei Maria da Penha sobre a mortalidade de mulheres por agressões no Brasil, 2001-2011. Epidemiol Serv Saúde. 2013:22(3):383-94. doi: 10.5123/\$1679-49742013000300003

15. Amaral LBM, Vasconcelos TB, Sá FE, Silva ASR, Macena RHM. Violência doméstica e a Lei Maria da Penha: perfil das agressões Penha: perfil sofridas por mulheres abrigadas em unidade social de proteção. Estud Fem. 2016;24(2):521-40. doi: 10.1590/1805-9584-2016v24n2p521

16. Instituto de Segurança Pública (Rio de Janeiro). Dossiê Mulher. 4. ed. Rio de Janeiro: Estudos; 2009.

17. Deslandes SF, Gomes R, Silva CMFP da. Caracterização dos casos de violência doméstica contra a mulher atendidos em dois hospitais públicos do Rio de Janeiro. Cad Saúde Pública. 2000;16(1):129-37. doi: 10.1590/S0102-311X2000000100013

18. Galvão EF, Andrade SM de. Violência contra a mulher : análise de casos atendidos em serviço de atenção à mulher em município do Sul do Brasil. Saúde e Soc. 2004;13(2):89-99. doi: 10.1590/ S0104-12902004000200009

19. Chiaperini A, Bérgamo $A L$, Bregagnolo LA, Bregagnolo JC, Watanabe MG de C, Silva RHA da. Danos bucomaxilofaciais em mulheres: registros do Instituto Médico-legal de Ribeirão Preto (SP), no período de 1998 a 2002. Rev Odonto Ciênc. 2009;24(1):71-6.
20. Santi LN de, Nakano AMS, Lettiere A. Percepção de mulheres em situação de violência sobre o suporte e apoio recebido em seu contexto social. Texto Context Enferm. 2010;19(3):417-24. doi: 10.1590/S0104-07072010000300002

21. Organização Mundial de Saúde. WHO Multi- country Study on Women's Health and Domestic Violence against Women: summary report of initial results on prevalence, health outcomes and women's responses. Geneva: World Health Organization; 2005.

22. Adeodato VG, Carvalho RR, Siqueira VR, Souza FGM. Qualidade de vida e depressão em mulheres vítimas de seus parceiros. Rev Saúde Pública. 2005;39(1):108-13. doi: 10.1590/S003489102005000100014

23. Griebler CN, Borges JL. Violência contra a mulher : perfil dos envolvidos em boletins de ocorrência da Lei Maria da Penha. Psico. 2013;44(2):215-225.

24. Campos CH. Desafios na implementação da Lei Maria da Penha. Rev Direito GV. 2015;11(2):391-406. doi: 10.1590/18082432201517

25. Heise L, Ellsberg M, Gottemoeller M. Ending Violence Against Women. Population Reports, Johns Hopkins University School of Public Health, Population Information Program. 1999;50(11):144.

26. Lindner SR, Coelho EBS, Bolsoni CC, Rojas PF, Boing AF. Prevalência de violência física por parceiro íntimo em homens e mulheres de Florianópolis, Santa Catarina, Brasil: estudo de base populacional. Cad Saúde Pública. 2015;31(4):815-826. doi: doi.org/10.1590/0102-311X00159913

27. Garbin CAS, Rovida TAS, Garbin AJl, Saliba O, Dossi AP. A importância da descrição de lesões odontológicas nos laudos médico-legais. RPG Rev Pós Grad. 2008;15(1):59-64.

28. Brasil. Lei n. 5081, de 24 de agosto de 1966. Regula o Exercício da Odontologia. Diário Oficial da União 1966; 26 ago. [citado 2016 Mar 20]. Disponível em: <http://www.planalto.gov.br/ ccivil_03/leis/L5081.htm>.

29. Pasinato W. Oito anos de Lei Maria da Penha. Entre avanços, obstáculos e desafios. Estud Fem. 2015;23(2):533-45. doi: 10.1590/0104-026X2015v23n2p533

30. Brasil. Lei n. 10.778, de 24 de novembro de 2003. Estabelece a notificação compulsória, no território nacional, do caso de violência contra a mulher que for atendida em serviços de saúde públicos ou privados. Diário Oficial da União 2003; 25 nov. [citado 2016 Mar 20]. Disponível em: <http://www.planalto.gov. br/ccivil_03/leis/2003//10.778.htm>.

Received on: 18/8/2016 Final version resubmitted on: 12/10/2016 Approved on: 6/2/2017 